Article

\title{
Ontario's Clean Water Act and Capacity Building: Implications for Serviced Rural Municipalities
}

\section{Sarah Minnes}

Memorial University of Newfoundland, 230 Elizabeth Ave, St. John's, NL A1B 3X9, Canada; sminnes@grenfell.mun.ca; Tel.: +1-613-453-0830

Received: 25 April 2017; Accepted: 10 July 2017; Published: 18 July 2017

\begin{abstract}
This research explores Ontario's Clean Water Act (S.O. 2006, c. 22) and its contribution to capacity building for rural municipalities impacted by source protection plans created under the Act. Source water protection (SWP) under the Clean Water Act (S.O. 2006, c. 22) is explored drawing from a capacity framework. A nested case study approach has been employed to allow for in depth exploration of the experience within the Cataraqui Source Protection Area and the North Bay-Mattawa Source Protection Area, where key informant interviews were conducted. Findings are outlined looking at four elements of capacity for SWP: institutional, financial, social, and technical/human. It was found that the process was successful for building capacity in the serviced rural municipalities involved, but did not provide any meaningful protection for areas reliant on private drinking water systems such as wells. Several improvements to the legislated process were suggested including greater flexibility for local circumstance and better methods for engagement of First Nations and the general public. It is unknown if this capacity will be sustained as the program continues and provincial funding is reduced. Reduced funding will particularly impact rural communities that lack the internal human and financial capacity to implement SWP policies without the assistance of provincial funding and conservation authority staff (who also rely on provincial/municipal funding sources). Ultimately, it was found that SWP in rural areas requires enforceable mandatory legislation; sustainable provincial funding and municipal fiscal frameworks to support ongoing SWP planning and implementation; technical aid at the regional level; and support and commitment to SWP at the local level (e.g., municipalities, local health units, landowners, residents and watershed users).
\end{abstract}

Keywords: source water protection; rural; capacity; rural drinking water

\section{Introduction}

The safety of our drinking water can be taken for granted until tragedy shakes that trust. In 2000, the contamination of Walkerton, Ontario's water supply by Escherichia coli O157:H7 and Campylobacter jejuni killed seven people and resulted in 2300 cases of serious illness [1,2]. The primary source of the contamination was manure from a nearby farm entering the municipal well [3]. One way to prevent such a contamination is keeping contaminants out of drinking water sources through source water protection (SWP) [4]. SWP is, "the development and implementation of policies, plans and activities to prevent or minimize direct or indirect release of pollutants into surface or groundwater resources currently used or intended to be used in the future as sources of drinking water" [5] (p. 944). SWP can be an important first line of defense in ensuring drinking water safety, and is an essential component in a multi-barrier approach to drinking water management $[2,6]$. SWP reduces costs of treatment and enhances drinking water safety [7-9]. Through SWP, "drinking water safety will be enhanced because treatment systems (especially in smaller communities) may not be able to eliminate all potential chemical, biological and radiological contaminants" [9] (p. 243). Being precautionary rather than reactive in managing drinking water contaminants can also lead to significant monetary 
savings. For example, the financial cost of Walkerton's contamination was over $\$ 64.5$ million $[1,4]$. The United States Environmental Protection Agency found that remediation of groundwater supplies after a contamination has already taken place can be 30-40 times more costly than preventative SWP measures, and the cost can be up to 700 times greater in rural areas [10]. However, SWP requires a certain amount of capacity that is often limited in rural communities with small populations, limited tax bases, and few (if any) technical staff [11,12].

This paper outlines findings from research exploring the implications for rural municipalities of Ontario's SWP legislation, policies and programs. This paper focuses on the findings pertaining to the municipalities with public drinking water systems that are included in the Cataraqui Source Protection Area (CSPA) and the North-Bay Mattawa Source Protection Area (NBMSPA)-two source protection areas under the Clean Water Act (S.O. 2006, c. 22) (CWA). The research questions addressed in this paper are:

i. What have been the successes and challenges with SWP planning and implementation of source protection plans in Ontario?

ii. Did the SWP planning process in Ontario, under the CWA, build capacity for SWP in municipally serviced rural municipalities?

This paper outlines through a capacity framework ways in which the CWA has improved the capacity for SWP for those rural municipalities with municipally operated drinking water systems in the case study regions. It is recognized that there are additional rural communities in these case study areas that either rely on private drinking water supplies or are First Nation communities. Meaningful discussion on rural communities' capacity for SWP for these types of other systems will be limited to further papers.

\subsection{Source Water Protection under Ontario's Clean Water Act (S.O. 2006, c. 22)}

Following the tragedy in Walkerton, Ontario, a public inquiry was conducted under the direction of Justice Dennis R. O'Connor. The Walkerton Inquiry produced two reports, Part 1 outlining the causes for the contamination and Part 2 providing strategies to avoid such a disaster in the future [13]. One of the key recommendations in Part 2 was the creation of watershed based source protection plans [4]. Though there were policy tools for municipalities in regard to SWP previous to the Walkerton tragedy, these were implemented in an ad hoc manner $[14,15]$. The CWA and it's regulations were created in response to Justice $\mathrm{O}^{\prime}$ Connor's recommendations $[2,8,15]$ and resulted in Ontario "making more comprehensive efforts to focus on source water protection than in other Canadian jurisdictions" [13] (p. 9). Ontario's Act was designed to be an integrated, science-based approach, using a governance structure that engaged multiple stakeholders. There are nineteen regional level source protection areas and regions that were created across the province, predominantly in densely populated Southern Ontario. There are sixteen source protection regions representing groupings of two or more conservation authority boundaries, and three source protection areas that were created using the boundary of one single conservation authority. Conservation authorities are local water management organizations, some existing since 1946, under the Conservation Authorities Act [2,15]. Conservation authorities (a lead conservation authority in the case of the source protection regions) have acted as the source protection authority, providing technical and administrative support to the source protection committee. Source protection authorities have coordinated the process under the CWA and were tasked with overseeing the assessment reports, the planning process, and ongoing implementation, monitoring, reporting and updating [16].

Each source protection area/region engaged multi-stakeholder source protection committees in order to assess threats and develop regional source protection plans $[8,15]$. The source protection authority appointed source protection committee members, with the exception of the chair who was appointed by the Minister of Environment and Climate Change. The source protection committees were composed of 10-22 members. The committees consisted of $1 / 3$ municipal sector; $1 / 3$ commercial, 
agriculture or industry; and 1/3 from the academic, professional, non-government organization sectors or the general public. If there were one or more First Nation communities in the source protection area/region, committees of 10,16 or 22 members had to include 1, 2 or 3 First Nation representatives, respectively. Liaisons such as public health representatives and Ministry of the Environment and Climate Change representatives were also invited to committee meetings [17].

Municipalities ensure mandatory policies under the source protection plans (i.e., those addressing significant threats) are implemented using planning tools such as by-laws and Official Plan policies [15] as well as through appointing a risk management official [18]. The implementation of the 22 source protection plans created is currently underway [19]. The Ontario CWA was specifically created to better protect drinking water supplies by building capacity in local areas, using multi-level governance structures to create source protection plans on a watershed basis [18]. To what extent the CWA has built capacity for SWP, particularly in the rural municipalities involved, will be explored in this paper.

\subsection{Source Water Protection and Capacity}

Best practices for SWP cannot be achieved without adequate capacity, particularly at the local level [9]. Generally, capacity for SWP is described as "the ability, or capability, of a local community to meet regulations, policies or standards that have been established" [12] (p. 22). Capacity for SWP is a multi-faceted notion that has been conceptualized as having four main elements: institutional, financial, social, technical/human [12,20,21] (Table A1 in Appendix A). Capacity is needed at multiple levels to successfully undertake SWP. Provincial and federal capacity can limit SWP efforts. It was argued that capacity in Canada for water management, as well as learning and sharing amongst jurisdictions, is deficient due to the federal government's failure of investment and leadership in national water management activities [21]. SWP also strains local technical skills and basic resources. Devolution of responsibilities to the local level must be matched with the proper power and resources to enact new responsibilities [22]. Best practices in SWP stress the need to develop capacity at the local level. Furthermore, support for SWP efforts at the local level need to be complemented with legalized institutional arrangements, financial support, technical support and data, as well as social capacity building (e.g., awareness building campaigns and opportunities for public engagement) [9]. Capacity building in water management and planning at the local community level can provide opportunities for future collaboration, better integration of water plans and the creation of networks that further understandings of catchment issues [23,24]. Moreover, there must be acceptance of source protection plans at the local level if local actors are also expected to enforce these plans [25]. Capacity building at the local level aids in developing this acceptance.

Overall, it is clear that enhancing local capacity for SWP is critical [5]. Municipalities are the frontline actors for drinking water management, with responsibilities for land use planning, water supply distribution, wastewater treatment, and SWP [25]. Unfortunately, capacity at the local level is particularly limited in rural communities, making places like Walkerton, Ontario (with a population of 4800 people at the time of the outbreak in 2000) [2] a prime place for drinking water safety vulnerabilities. SWP capacity related limitations in rural areas include (but are not limited to): lack of technical expertise and staff; small revenue bases; accessibility difficulties; and large geographies $[5,11,21,26]$. For example, Canada-wide studies suggest that insufficient financial capacity to hire expert consultants, technical expertise and other human capital, can be a barrier to SWP in small to medium water system operations [7] (p. 388). This paper will evaluate through a capacity framework (Table A1) if and how the process under the CWA has built capacity for SWP in rural municipalities impacted by the plan.

\section{Materials and Methods}

A nested case study approach was employed in this research [27] to allow for in depth exploration of the experience within two rural regions. The two SWP regions (displayed in Figure 1) chosen were the CSPA in Eastern Ontario and the NBMSPA in "near north" Ontario. These case study regions 
were ideal because of their largely rural composition. For this research, the very inclusive definition of rural from the Ontario Ministry of Agriculture, Food and Rural Affairs was used. This definition outlines rural as: "all Statistics Canada's census subdivisions (including lower-tier and single-tier municipalities) that meet at least one of the following criteria:

- Have a population of less than 100,000 people

- Have a population density of 100 people/km² or less" [28] (para. 8).

Under this definition every municipality in the case study regions, with the exception of Kingston, ON in the CSPA, are considered rural [29-31].

The research began with an extensive literature review and document analysis, which included academic literature and policy/document analysis of Ontario's drinking water legislation, regulations, policies and programs and other related documents such as websites and source protection committee meeting minutes. Further work was also done on refining definitions and indicators of capacity for SWP (Table A1). Once definitions and indicators were refined, interview guides were created and semi-structured key-informant interviews were conducted. More information on the interviews conducted and analysis is explained below.

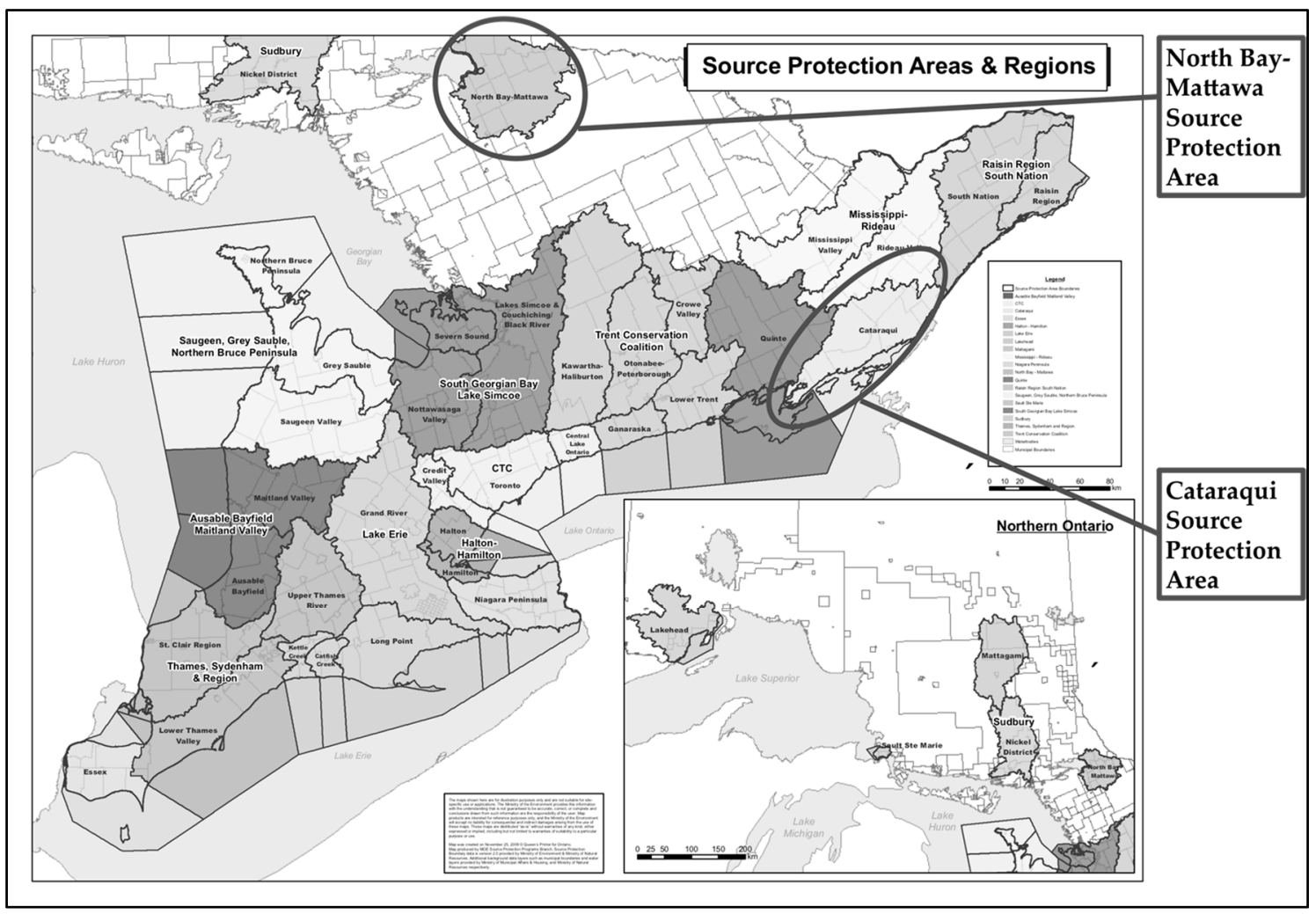

Figure 1. Case Study Locations [32].

\subsection{Semi-Structured Key-Informant Interviews}

To answer the above research questions 31 key informant interviews were conducted, with various stakeholders in both case study regions (12 participants in NBMSPA; and 14 participants in CSPA), as well as experts with a provincial perspective (five in total). One key informant decided to withdraw their information from the study, resulting in 30 interviews being used in analysis. All key informant interviews were conducted in confidence as per the informed consent process. The Grenfell Campus Research Ethics Board granted ethical clearance to this research and found the research to be in ethical compliance with the Tri-Council Guidelines (reference number 20161916). Key 
informants were targeted based on their familiarity with the rural context as well as their role within the source protection planning and implementation process. Semi-structured interviews (a form of qualitative interviewing) were conducted with key informants, using two interview guides. One guide was created for provincial government/provincial wide informants, and one guide was created for regional informants that contained more specific questions about the planning and governance process. The interview guides contained questions related to various topics, including questions assessing elements for capacity for SWP (Table A1). Other factors related to SWP topics were also explored including questions relating more specifically to watershed governance. Findings directly related to watershed governance will be limited to further papers. A semi-structured interview method was chosen, as opposed to a structured interview design, to allow for robust and meaningful discussion with key informants. This qualitative, more conversational interview approach facilitates two-way interactions, delving into specific contextual conditions of interviewees [27]. Yin (2011) explains about this approach, "this aim suits one of the fundamental objectives of qualitative research, which is to depict a complex social world from a participant's perspective [27] (p. 135). Given the complexity of the subject matter being discussed, this approach was deemed the most appropriate.

In total, diverse perspectives on the topic were consulted analyzing transcripts and one set of interview notes from nine source protection committee members (source protection committee members interviewed represented a range of affiliations including actors from agriculture, business, municipal, academic, and public health sectors), four provincial staff, eight upper and lower tiered municipal staff and elected officials, five conservation authority/Conservation Ontario staff, and four non-governmental or consultants with expertise in rural SWP. A further breakdown of the key informants in each case study region is displayed in Table 1. General identifiers have been used in this article to protect the confidentiality of the participants.

Table 1. Key Informant Interviews Analyzed $(n=30)$.

\begin{tabular}{cccccc}
\hline Sector & Identifier in Article & Total & CSPA & NBMSPA & Ontario Wide \\
\hline Source protection Committee Member & SPC Participant & 9 & 4 & 5 & 0 \\
\hline Provincial Staff & Provincial Participant & 4 & 3 & 1 & 0 \\
\hline $\begin{array}{c}\text { Upper/lower Tiered Municipal Staff and } \\
\text { Elected Officials }\end{array}$ & Municipal Participant & 8 & 4 & 4 & 0 \\
\hline $\begin{array}{c}\text { Conservation Authority/Conservation } \\
\text { Ontario Staff }\end{array}$ & CA Participant & 5 & 2 & 1 & 2 \\
\hline $\begin{array}{c}\text { Non-Governmental Expert } \\
\text { or Consultant }\end{array}$ & Other Participant & 4 & 0 & 1 & 3 \\
\hline \multicolumn{1}{c}{ Total } & 30 & 13 & 12 & 5 \\
\hline
\end{tabular}

\subsection{Analysis}

Analysis was conducted using predetermined indicators, coding interview transcripts (or in one case interview notes). Indicators facilitating capacity for SWP can be found in Table A1. Coding was conducted using NVivo qualitative research software, classifying key informant responses according to each element identified in Table A1. After general coding was conducted, the researcher went back to each code and coded it for displaying either the presence or absence of the element (using the indicators for each element). After the second round of coding, a chart was made of the percentage of interviews in each case study region and from Ontario wide interviews, that discussed the element and confirmed through their answers the presence or absence of the element. Further analysis was done from these codes, delving into the evidence and deriving conclusions from both the percentages and the raw qualitative data. The last step of analysis involved taking the key findings (i.e., findings confirmed by the greatest number of key informants) and creating charts of the number of key informants who supported each key finding. 


\section{Results}

This section outlines the findings from the key informant interviews conducted regarding the successes and challenges of the CWA and implications of the Act on the capacity for SWP in particularly rural areas. For the purposes of this paper, findings have been derived for municipalities with public drinking water systems that were included in the source protection plans for the CSPA and the NBMSPA. Therefore, the findings exclusively apply to serviced municipalities (i.e., municipalities with drinking water systems owned by the municipality). Table 2 provides a summary for the presence of or absence of all elements of capacity according to region. Further explanations of these findings are described in subsequent sections. Table 2 outlines the percentage of interviews that discussed either the presence or absence of the element of capacity. Many informants confirmed both the presence and absence of an element. Below in Table 2, $n$ represents the number of interviews which discussed the element (not all interviewees discussed each element as they did not have expertise or experience in that area and could not therefore answer the interview questions relating to the element). Indicators used to assess presence or absence of an element can be found in Table A1. To further support overall findings, tables have been provided in Sections 3.1-3.4 denoting how many participants supported each major finding related to each element of SWP capacity.

Table 2. Interviews Indicating a Presence and/or Absence of Elements of Capacity.

\begin{tabular}{|c|c|c|c|c|c|c|c|c|c|c|c|}
\hline \multicolumn{3}{|c|}{ Institutional } & \multicolumn{3}{|c|}{ Financial } & \multicolumn{3}{|c|}{ Social } & \multicolumn{3}{|c|}{ Technical/Human } \\
\hline & + & - & & + & - & & + & - & & + & - \\
\hline $\mathbf{C}(n=12)$ & $100 \%$ & $83 \%$ & $\mathbf{C}(n=11)$ & $100 \%$ & $64 \%$ & $\mathbf{C}(n=9)$ & $100 \%$ & $78 \%$ & $\mathbf{C}(n=11)$ & $100 \%$ & $45 \%$ \\
\hline $\mathbf{N B}(n=12)$ & $100 \%$ & $83 \%$ & $\mathbf{N B}(n=11)$ & $100 \%$ & $55 \%$ & $\mathbf{N B}(n=12)$ & $92 \%$ & $75 \%$ & $\mathbf{N B}(n=12)$ & $100 \%$ & $67 \%$ \\
\hline $\mathbf{O}(n=5)$ & $100 \%$ & $100 \%$ & $\mathbf{O}(n=5)$ & $100 \%$ & $60 \%$ & $\mathbf{O}(n=1)$ & $100 \%$ & $0 \%$ & $\mathbf{O}(n=4)$ & $100 \%$ & $100 \%$ \\
\hline
\end{tabular}

Notes: + = Presence; $-=$ Absence; $\mathrm{C}=\mathrm{CSPA} ; \mathrm{NB}=$ NBMSPA; $\mathrm{O}=$ Ontario Wide; $n=$ The number of interviews that discussed the element.

\subsection{Institutional}

Institutional capacity for SWP refers to the legislation, regulations, policies, protocols, governance arrangements and delegation of responsibility to plan and enact SWP [12,20]. In total, 29/30 interviews conducted discussed institutional capacity for SWP under the CWA. All of these participants noted the process under the CWA as successful in raising institutional capacity for the municipalities included in the source protection plans (Table 2). Firstly, 24 participants noted the enforceable and mandatory nature of the CWA legislation itself as integral to raising the institutional capacity for SWP (Table 3). The Walkerton tragedy, and the subsequent Walkerton Inquiry [3,4] was noted by 20 participants as the driving force for stricter legislation for safe and clean drinking water in Ontario. Twenty informants explained that the CWA legislation and associated regulations delineated governance processes and protocols for how to create source protection plans and roles within implementation (Table 3). For example, the source protection committees were regulated through Ontario regulation 288/07 of the CWA. The governance choice to have the conservation authorities as the source protection authority was a natural fit, as conservation authorities already had experience working with municipalities at a watershed level. Source protection committee members had to go through an interview process, and conservation authorities appointed committee members. Agricultural representatives appointed by the conservation authorities were elected in local elections facilitated by the Ontario Farm Environmental Coalition and the County Federations of Agriculture. Chairs were appointed by the Ministry of the Environment and Climate Change. The source protection committee had a good mix of actors, representing a diverse range of views (social, economic and environmental). One SPC Participant explained that the committee," ... was a good opportunity to network and exchange ideas and you know ... put me in touch with some of the folks that I wouldn't normally be in touch with" (SPC Participant). The process allowed for ample discussion and debate, with topics of concern spanning meetings, and often requiring additional research by the source protection authorities and provincial liaisons. All decisions were based on consensus. 
Table 3. Key Findings for Institutional Capacity.

\begin{tabular}{lc}
\hline \multicolumn{1}{c}{ Indicators of Presence } & No. of Interviews Confirming Indicator \\
\hline Creation of Mandatory and Enforceable Legislation. & 24 \\
\hline $\begin{array}{l}\text { Creation of a Clear Governance Structure and Delineation of } \\
\text { Implementation Responsibilities. }\end{array}$ & 20 \\
\hline \multicolumn{1}{c}{ Indicators of Absence } & No. of Interviews Confirming Indicator \\
\hline $\begin{array}{l}\text { The Exclusion of Certain Communities from the Mandatory Protection of the } \\
\text { CWA (e.g., First Nation Communities, Private Drinking Water Systems). }\end{array}$ & 25 \\
\hline $\begin{array}{l}\text { Not Enough Flexibility for Locally Relevant Concerns (e.g., Great Lakes, } \\
\text { Private Well Clusters, Pipelines). }\end{array}$ & 22 \\
\hline $\begin{array}{l}\text { Lack of Involvement of First Nation Communities' in Source Protection } \\
\text { Committees and Plans (There was Indication by Key Informants this is } \\
\text { Being Looked into). }\end{array}$ & 10 \\
\hline $\begin{array}{l}\text { Program and Technical Guidelines were not Fully Scoped Resulting in } \\
\text { Inefficiencies, Frustrations, and an Overall Very Lengthy Process. }\end{array}$ & 9 \\
\hline
\end{tabular}

As discussed above, the CWA was noted by 24 participants as particularly effective in giving the created source protection plans the needed legislative power to be enforced through clear implementation responsibilities and consequences, such as Official Plan and by-law conformity [17] (Table 3). In the creation of the source protection plans, the source protection committees strategically evaluated where gaps in current legislation existed. The policies under the plan aimed to fill these gaps. In addition to the CWA, other complementing legislation ensures implementation of SWP policies. These other prescribed instruments issued by the provincial government that contain provisions that can be used in SWP include the: Environmental Protect Act (1990); Ontario Water Resources Act (1990); Pesticides Act (1990); Safe Drinking Water Act (2002); Aggregate Resources Act (1990); Nutrient Management Act (2002) [31]. Instruments that are enabled under Ontario legislation that are relevant to source protection planning are listed in Table 4. For example, Section 19 of the Safe Drinking Water Act (2002) outlines a statutory standard of care that requires those persons that have decision-making authority over municipal drinking water systems to act honestly, competently and with integrity when making decisions regarding municipal drinking water systems. Responsible parties (including municipal councillors) can be prosecuted and convicted under this section [33].

Table 4. Ontario Legislation Relevant to Source Protection Planning [31] (pp. 28-29).

\begin{tabular}{|c|c|}
\hline Act & Relation to Source Protection Planning \\
\hline Environmental Protect Act (1990) & $\begin{array}{l}\text { Approvals for the use, operation, establishment, alteration, enlargement or extension } \\
\text { of waste disposal sites or waste management systems } \\
\text { Approvals issued for the use, operation, establishment, alteration, enlargement or } \\
\text { extension of waste disposal sites or waste management systems, or the establishment, } \\
\text { alteration, extension or replacement of new or existing sewage works } \\
\text { Renewable energy approvals }\end{array}$ \\
\hline Ontario Water Resources Act (1990) & $\begin{array}{l}\text { Permits to take water } \\
\text { Approvals to establish, alter, extend or replace new or existing sewage works }\end{array}$ \\
\hline Pesticides Act (1990) & $\begin{array}{l}\text { Pesticide permits for land exterminations, structural exterminations and } \\
\text { water exterminations }\end{array}$ \\
\hline Safe Drinking Water Act (2002) & $\begin{array}{l}\text { Drinking water works permits } \\
\text { Municipal drinking water licences }\end{array}$ \\
\hline Aggregate Resources Act (1990) & $\begin{array}{l}\text { Site plans included in applications for licenses } \\
\text { Licenses to remove aggregate from pits or quarries } \\
\text { Site plans accompanying applications for wayside permits } \\
\text { Wayside permits to operate pits or quarries } \\
\text { Site plans included in applications for aggregate permits } \\
\text { Aggregate permits to excavate aggregate or topsoil }\end{array}$ \\
\hline Nutrient Management Act (2002) & $\begin{array}{l}\text { Nutrient Management Strategies and Plans } \\
\text { Non-Agricultural Source Material (NASM) Plans }\end{array}$ \\
\hline
\end{tabular}

Binding policies were created in the source protection plans for each region including efforts such as outreach and education, raw quality samplings, and emergency and spill response plans [30,31]. The types of policies were outlined in the plans along with rationales, prescribed legal effects by tools, 
and prescribed instrument decisions that must conform to a policy (e.g., Official Plans). It should be noted not all policies created in the source protection plans were mandatory. The types of policies range from: must conform/comply with policies; have regard to policies; and non-legally binding policies. In short, a must conform/comply policy is instituted to address a significant drinking water threat/condition, as outlined in the plan $[30,31]$. Though the non-legally binding policies have no legal impact, there was indication from a provincial government staff member that the Minister of Environment and Climate Change read and is considering all non-binding policies. One provincial government staff member explained in regard to the non-binding policies included in the plans, "Their needs to be a rationale for why we are not implementing that. So kudos to the people that really did push the boundaries for us because it really does highlight for us that we could be doing a better job in certain areas" (Provincial Participant). This indicates the inclusion of the non-binding policies were not done in vain by the source protection committees, and could lead to regulatory reform in the future.

Part IV of the CWA lays out the regulation of drinking water threats identified in the source protection plans and the various roles in enforcement shared between municipalities, boards of health, planning boards, source protection authorities, and provincial actors. Mechanisms for implementation are also included in the CWA legislation regarding monitoring programs and annual progress reports. Twenty key informants noted that even though they may not agree with decisions made in source protection plans, all implementers of the plans have clear responsibilities, and know their obligations in implementation (Table 3). The source protection authorities (i.e., the conservation authorities) as well as the risk management officials play an important role in monitoring and enforcement efforts. The risk management official and inspector help address legally binding policies under the source protection plan, and work with implementers (e.g., municipalities, businesses, landowners) to ensure policies are being followed. It was explained by a rural municipal Risk Management Official on the role, "basically I'll ask you really nicely to do it. Then I'll tell you to do it, then I will order you to do it. And if you don't do it on our order I will do it and put it on your tax ill" (Municipal Participant). Evidently, there are clear steps to ensure the "must conform" policies under the source protection plans are abided by. However, as will be discussed in subsequent sections, there was some concern expressed by key informants regarding funding for further iterations of the plan and the same level of continued support for implementation measures.

Annual progress reports are collected by conservation authorities and submitted to the Ministry of the Environment and Climate Change. Conservation authorities are also able to submit letters to the Ministry of the Environment and Climate Change on items to consider in future plan reviews and iterations. Nine participants noted this first round of planning was rolled out in stages, causing source protection committees and authorities to go back and re-evaluate decisions or re-do certain activities related to the assessment report to address refinements to the Tables of Drinking Water Threats. (The Tables of Drinking Water Threats is a document issued by the Ministry of the Environment and Climate Change and contains a series of tables of potential drinking water threats. The document identifies under which circumstance the listed drinking water threats can be categorized in the source protection plans as a significant, moderate or low drinking water threat [30].) The narrowing scope of the work as the program rolled out was often a source of frustration for source protection committee members (Table 3). This resulted in much inefficiency in the planning process. One municipal staff member said, "... it was a little bit like two steps forward, three steps back" (Municipal Participant). Another Conservation authority staff member said,

“We weren't always 100\% sure about some of the technical rules for the assessment work, and those are actually being reviewed right now by the province, which is good. In any kind of process the first phase, the first step is your base model and then you make iterative improvements and we are pleased to see that the province is going to make improvements for the second round. Things are going to be better and better" (CA Participant).

There is positivity regarding the next round of planning, and hopes that it will be more clearly scoped as the program matures. 
As mentioned, the majority of participants (24) noted having SWP legislated under the CWA was beneficial in raising institutional capacity (Table 3). However, there were also concerns regarding the prescriptive nature of the CWA and ways in which the CWA restricted the planning process and local autonomy in deciding what could be included in the source protection plans. For example, the Tables of Drinking Water Threats were important in making decisions technically defensible. However, 22 participants noted the process being overly rigid and sometimes insensitive to specific local issues and circumstances (Table 3). One such example is the ability to address issues with Great Lakes intakes in the CSPA. Another example includes allowing the Energy East pipeline to be considered a threat in the NBMSPA. Though there was some flexibility for local circumstance and to add local threats to the list of prescribed activities needing to be addressed, it did not always cover every circumstance. On the other hand, the plans had to include legally binding policies for municipalities for threats that would never be able to occur in the areas designated or would require policies that were redundant. For example, a municipal staff member explained,

"... airplane de-icing, salt and storage, winter snow storage that were identified as threats and that we zoned for. None of those activities would even be able to occur in the IPZ-1 or 2 areas. Because it is basically just a shoreline in the urban area so you get into the threats for the issue contributing area a little bit more possibly there. So, the ones in town, I mean that area is already developed and not getting any kind of airport anytime" (Municipal Participant).

The exclusion of certain communities from the mandatory protection of the CWA was noted by 25 key informants as a shortcoming of the legislation (Table 3). As of now First Nation communities, municipally serviced systems outside of current source protection areas/regions, and those drinking water systems not part of municipally owned drinking water systems (e.g., private wells, private surface water systems) were excluded from requiring mandatory source protection under the CWA. There were no First Nation communities located in the CSPA. In the NBMSPA the Nipissing First Nation decided not to be part of the process. One provincial government participant explained there is currently a mandate at the provincial level for better inclusion of First Nations in the process. There is the ability to elevate either a First Nation community or a clustering of wells into source protection plans under the CWA [17]. In the NBMSPA, they did choose to elevate a private well clustering in the community of Trout Creek (which has now been amalgamated into the Municipality of Powassan) into their plan. However, the town fought to opt-out of the process in the end. This was due to a variety of reasons, mainly concerns of house resale values if their well to septic bed distance was labeled as a significant drinking water threat. Though the plans did not intentionally mandate protection for private drinking water sources, some of these sources were protected due to their location within a municipal vulnerable area. For example, if a private well fell within a vulnerable area of a municipal drinking water intake, there were legally enforceable measures under the source protection plans and other legislation protecting this source. For example, the Building Code Act, 1992 and the Building Code require mandatory maintenance inspections of every on-site sewage system (e.g., septic system) in vulnerable areas where these systems are identified as significant threats to a source of drinking water (e.g., wellhead protection areas A and B) [30]. The legislation does allow for planned municipal water systems to be elevated into the plan.

The process under the CWA did raise the institutional capacity for SWP in rural communities in the source protection areas, most notably for creating plans that had policies that must be implemented. It was mentioned by 11 participants, especially for small rural communities with limited financial capacity and staff, that voluntary actions are often not implemented. Ultimately, institutional measures such as enforceable legislation and guiding governance structures are needed in SWP, and were strongly displayed in the process under the CWA. 


\subsection{Financial}

Financial capacity for SWP refers to the ability to acquire adequate funds to pay for SWP efforts as well as for ongoing planning, governance and management efforts [12,20]. In total, 27/30 interviews conducted discussed financial capacity for SWP under the CWA. As highlighted in Table 2, evidence of the presence of financial capacity was strong in each case study region, and indicated as present from the Ontario wide informants. The majority of comments indicating a presence of financial capacity referred to the funding available during the planning process and in the creation of the terms of reference, the assessment report, and the source protection plans themselves (Table 5). Provincially, the Ministry of the Environment and Climate Change have invested over \$250 million in the program thus far [19]. It was explained by a municipal staff member, "The province paid for everything. So they paid through the conservation authorities, the conservation authorities hired the consultants. The township didn't have to pay anything beyond the staff time to review and implement" (Municipal Participant). Provincial funding programs such as the Source Protection Municipal Implementation Fund was imperative in funding both voluntary and mandatory implementation efforts (including staffing costs). This funding was noted by six participants as being especially important for rural municipalities that would not have been able to achieve delegated duties without additional resources. Municipal key informants noted that, thus far in these early stages of implementation, SWP under the CWA has not been a financial burden on them as there has been sufficient provincial funding. Landowners who implement plan policies have also been provided with funding through the Ontario Drinking Water Stewardship fund that helped with efforts such as septic system replacements and the general outreach and education of people that were going to be impacted by the source protection plans. There have also been specific funding programs for farmers and support from the Ministry of Agriculture, Food and Rural Affairs through their nutrient management legislation and plans. However, one participant expressed some concerns about this funding being very competitive and requiring a farm plan, resulting in individuals having to apply a couple times before funding was granted.

Table 5. Key Findings for Financial Capacity.

\begin{tabular}{lc}
\hline \multicolumn{1}{c}{ Indicators of Presence } & No. of Interviews Confirming Indicator \\
\hline $\begin{array}{l}\text { Over } \$ 250 \text { million of provincial funding provided to the program } \\
\text { and related activities }\end{array}$ & 27 \\
\hline \multicolumn{1}{c}{ Indicators of Absence } & No. of Interviews Confirming Indicator \\
\hline $\begin{array}{l}\text { Ongoing implementation, monitoring and evaluation funding from } \\
\text { the provincial government is unknown. This impacted some } \\
\text { decisions made in source protection plans (i.e., inclusion of private } \\
\text { well clusters, policies requiring risk management officials). }\end{array}$ & 16 \\
\hline $\begin{array}{l}\text { Financial ownership of the program is lacking at the municipal level, } \\
\text { especially in rural municipalities. }\end{array}$ & 6 \\
\hline $\begin{array}{l}\text { Diminishing provincial funding has resulted in a loss of human } \\
\text { capacity at the conservation authorities. }\end{array}$ & 6 \\
\hline
\end{tabular}

Despite strong consensus regarding the presence of financial capacity for the process under the CWA, there were also less frequent comments regarding the absence of financial capacity. For example, 16 participants expressed concern about the impacts of unknown future funding from the provincial government for implementation, monitoring and evaluation of source protection plans (Table 5). It was explained in the Cataraqui Source Protection Plan,

"most municipalities stressed their unwillingness to implement policies, especially non-legally binding policies, unless there is provincial funding and other resources made available to do so. Concerns were also raised by local residents that could be impacted by the Plan" [30] (p. 7) 
In the village of Mallorytown in the CSPA, there was significant push back from residents and municipal officials on implementing SWP policies for a 17-unit apartment building obtaining water from a well. The building and the well are both owned by the United Counties of Leeds and Grenville, therefore triggering the CWA legislation, as a public water system [30]. One source protection committee member explained that the concerns were mainly due to financial implications of implementation such as changes to septic fields, upgrades to oil tanks, and impacts on future development. With ongoing implementation funding unknown, this impacted some of the decisions that the source protection committees made. For example, one source protection committee member explained, "We specifically did not go down the path of having a risk management officer. You know because had that happened then that would have been costs to all of the municipalities, that there was no funding for" (SPC Participant). As noted in the previous section, the community containing the cluster of private wells that were elevated into the source protection plan in the NBMSPA was also concerned about implementation costs and implications on housing prices. Under the CWA, municipalities are responsible for implementing policies and funding risk management officials. This research shows that financial ownership by municipalities may be lacking, especially for those rural municipalities in the case study regions.

It was clear that municipalities with supportive councils that prioritized water were more optimistic about implementation. One consultant stated, “ ... if you want to have a safe water supply you have to be prepared to pay for it" (Other Participant). However, municipal ownership of the full fiscal responsibilities of SWP was not always the case. Six participants indicated financial ownership of the program is lacking at the municipal level, especially in rural municipalities (Table 5). One conservation authority staff member explained,

"They are trying to instill a sense of ownership in the municipalities. It is your drinking water, your people, you help protect it from source to tap. But at least in our area the municipal councils still see it as a shared responsibility with ongoing provincial funding and support" (CA Participant).

Clearly, municipalities are still relying on provincial government support for SWP. A concern that will be outlined more in Section 3.4 is the impact that diminished funding has had on staff retention at the conservation authorities. Six participants expressed the loss of human capacity at the conservation authorities as a concern resulting from a loss of financial capacity (Table 5). These lost conservation authority staff held the institutional knowledge of the SWP planning process and were important actors in aiding municipalities in implementation. One conservation authority staff member mentioned the importance of being creative with funding and staff roles, engaging staff on other mandates so they are not lost. This issue speaks to the larger issue of how reduced financial capacity will impact institutional, technical/human and social capacity for SWP. This reduced capacity due to declining provincial funding is especially concerning for small rural municipalities who lack internal staff for SWP efforts.

Though provincial funding is not guaranteed into the future, a provincial staff representative explained that the CWA and SWP in general is "embedded in the way we do business" (Provincial Participant). This does suggest that there will be the availability of some continued funding for municipalities in the future. During the annual reviews conducted by conservation authority staff, future SWP research and activities are prioritized and funding is requested from the provincial government for these activities. This funding is currently on a year-by-year basis. Regarding funding for SWP, one conservation authority staff member explained, "Is there enough? There is never enough. And the more you learn the more you find you need to do" (CA Participant). One conservation authority staff member explained in regard to rural municipalities,

"small rural communities often have less capacity and financial resources to assess conditions and threats to their drinking water supplies on an ongoing basis. They generally rely more on the Province to assist in protecting the residents. Some find efficiencies by pooling resources with other nearby communities" (CA Participant). 
Into the future, further attention will be needed for sustainable fiscal frameworks for SWP implementation at the municipal level. This will be increasingly difficult for rural municipalities, and will require a great deal of prioritization of such efforts, in already limited budgets.

\subsection{Social}

Social capacity for SWP refers to the social factors that influence SWP governance and implementation. This includes social norms (e.g., values, attitudes, behaviours, sense of place, trust, reciprocity, commitment and motivation) that impact public awareness, stakeholder involvement, community support, and public and private partnerships in SWP efforts. This also incorporates structural networks, communications and the relationships between different interest groups and actors [12,20]. In total, 22/30 interviews conducted discussed social capacity for SWP under the CWA, with most of the interviews displaying high levels of social capacity elements (Table 2). When considering factors in social capacity such as leadership at the watershed level, the conservation authorities acting as the source protection authority served a vital function as the regional experts. The conservation authorities played both the role of a facilitator but also as often a negotiator between the provincial and local governments. When conducting the assessment reports and creating the plan there was a great deal of data sharing amongst the source protection authorities, creating structural networks of support. More prominently in the CSPA, as it neighbours other source protection areas, it was noted by a provincial government participant that there were effective coordination and collaboration amongst the five Eastern Ontario source protection areas/regions. The provincial government Ministries were also open in sharing data (such as between the Ministry of the Environment and Climate Change and the Ministry of Natural Resources and Forestry). In addition, both case study regions shared SWP related data with local academic institutions and included academic representatives on their source protection committees.

Thirteen participants noted the composition of the source protection committees contributed to increasing social capacity (Table 6). Involving a diverse range of stakeholders in the decision-making process created an environment where linkages were either created or strengthened (if existed before the process began) between municipal and provincial agencies, municipalities that shared watershed jurisdictions, community groups and other local experts such as public health liaisons. A source protection committee member explained,

"Where an issue crossed over boundaries we had a process, science based, which helped prove the data or findings to everyone, so that people could not get back into their corner of local autonomy and say well, thanks but we are going to do it this way. We were all in this thing together" (SPC Participant).

As represented by this quotation, a critical component of source protection committee participation was the learning and capacity building that occurred with the members around the table. Representatives had a clear idea of why decisions were being made, and would then reach out to the groups they were representing to explain the rationale behind decisions made. A great deal of time and resources were invested in educating source protection committee members (which will be discussed more in Section 3.4). Source protection committee members noted a high commitment level to the process, despite long meetings and a great deal of homework. Decisions were based on consensus, often debating the social, economic and environmental consequences of decisions. Even if it took several meetings to reach an agreement, the process for the active exchange of ideas and viewpoints was entrenched in the CWA and its regulations. 
Table 6. Key Findings for Social Capacity.

\begin{tabular}{lc}
\hline \multicolumn{1}{c}{ Indicators of Presence } & No. of Interviews Confirming Indicator \\
\hline $\begin{array}{l}\text { Process Provided Educational Opportunities to the Public as Well as } \\
\text { Municipal Staff and Elected Officials, Increasing Awareness about SWP. }\end{array}$ & 16 \\
\hline $\begin{array}{l}\text { Process Convened a Diverse Range of Stakeholders Together on the } \\
\text { Source Protection Committee, Creating New Networks for } \\
\text { Communication and Data Sharing. }\end{array}$ & 13 \\
\hline \multicolumn{1}{c}{ Indicators of Absence } & No. of Interviews Confirming Indicator \\
\hline $\begin{array}{l}\text { Understanding of the Need for SWP and Drinking Water in General was } \\
\text { Variable in Both Regions. }\end{array}$ & 13 \\
\hline $\begin{array}{l}\text { Better Engagement Techniques are Required that Address Barriers to } \\
\text { Engagement (e.g., Long Distances to Travel to Events, Lack of an } \\
\text { Understanding of the Technical Material, Rural Residents' Aversion to } \\
\text { Regulation and Land Use Restrictions) }\end{array}$ \\
\hline
\end{tabular}

Face-to-face interaction with committee members and other stakeholders generated trust for policy decisions. For example, in the NBMSPA the conservation authority worked with local lake associations in a tree give away program to reduce erosion and pollution in selected contributing areas. Direct engagement through source protection committee members was noted especially important for groups such as business owners and the agricultural sector. It was explained the relationship sometimes between the agricultural community and conservation authorities could be strained. It was explained, "I made some comments in the review of the conservation authority mandate to that degree. They are not seen as a friendly face in the farm community in most cases. And so they got hurdles to overcome" (SPC Participant). Traditionally, and especially with SWP matters, the agricultural community has received some blame in contaminating drinking water sources through agricultural practices such as the spreading of fertilizers. For example, in the NBMSPA there was dispute between agricultural groups and environmental non-governmental organizations on the cause of phosphorus loading in one contributing area. One risk management official said "you almost have to be a policy expert to be a farmer" (Municipal Participant). Especially since the Walkerton tragedy, the agricultural community has been highly regulated through the Nutrient Management Act, as well as many SWP policies in the source protection plans relating directly to agricultural practices. The Ontario Federation of Agriculture, the Ontario Farm Environmental Coalition and the Ontario Ministry of Agriculture, Food and Rural Affairs did contribute to building both social capacity and technical capacity in this regard by connecting agricultural representatives across the province during additional training sessions and improving access to technical support on specific issues.

There are no First Nation communities in the CSPA. Nipissing 10 First Nation Reserve (Nipissing First Nation) is located within the NBMSPA [31]. Though invited to the committee table, they did not participate. It was suggested by one source protection committee member that this was because the policies under the source protection plan did not impact them, and having to drive to North Bay for meetings every month would be very inconvenient. The same source protection committee member recommended that participation tools should allow for greater flexibility, such as letting participants join through web-conferencing tools.

Sixteen participants said that the CWA embedded public participation and other outreach and education in its planning process (Table 6). This included efforts such as public consultation and open house nights, community barbeques, community round table events, shoreline restoration programs, and the use of public service announcements on the television. However, in both regions attempts to engage the public were not always well received. Ten participants indicated that better engagement techniques are required that address barriers to engagement (Table 6). One source protection committee member explained, "... the areas where there were no problems, it was like moving mountains to get people to attend" (SPC Participant). Generally, in the areas where there was a perceived issue with either drinking water or the impacts of the potential policies under the CWA, there were higher 
participation rates at public events. However, if there were no perceived issues, public engagement was limited. As all SWP efforts require ongoing actions from the public this poses a problem for the present and future implementation of SWP measures. It was mentioned by some informants that the information delivered was very technical and there was confusion around the language used. This lack of understanding made public consultations more about information sharing than meaningful consultation. One municipal participant (with expertise in environmental science) explained, "I read the final report, but I have to go back and look at all the codes because it's like, what the heck, it's in latin" (Municipal Participant). These technical reports are generally not helpful for the general public. Five participants stressed that the lay summaries provided were very important for ensuring needed behavior changes were being conveyed to the public. One provincial government participant explained further about issues with public engagement,

\begin{abstract}
As far as contacting the landowner and helping them understand, their attendance at all our public [events], our open houses and meetings [were] low. Which tends to translate into they don't understand. They were contacted multiple times. Either through stewardship funding available for you know surveys and questionnaires about what we need to know, what activities are happening on your property so that we can have a good conversation with you. All the consultation on the terms of reference, the assessment report, the plan. Here are the policies that apply to you, this is what it is going to mean to you. But again until someone really shows up on your property and at that point, that's where we as a province said we need to make sure we are supporting that. Because when they come to your door and they ask, there needs to be somebody there that can answer. And there also has to be that understanding that there is enforcement behind it should you not comply. So, yeah. We are still working through that piece (Provincial Participant).
\end{abstract}

Despite repeated attempts to engage the general public during the planning phase it was suggested by one provincial government staff member that engagement may increase during the implementation of the source protection plans as the public realized how exactly policies will impact them. One source protection committee member suggested in the future that there be more incentives for participation, "... there would have to be some rewards or motivation to keep people engaged and having them involved in these types of projects" (SPC Participant). Addressing barriers to engagement also has to incorporate understanding those you are trying to engage. Six participants explained that rural landowners' sensitivity to restrictions on land use might dissuade them from working collaboratively with SWP officials or see their role in SWP.

Thirteen participants described people's understandings of drinking water risks as "variable" in their regions (Table 6). One participant stated that political will at the municipal level, especially in rural towns, was essential to the council's adopting of non-binding policies outlined in the source protection plans. The tragedy in Walkerton displayed what can happen when those responsible for water systems are negligent, and the fear of repeating this tragedy was a catalyst for stricter source protection by-laws and practices at the municipal level. In addition, as previously outlined, legal ramifications for decisions concerning drinking water systems has made municipal actors more aware of drinking water issues and cognizant of the impacts of their decisions. There was evidence in both regions of rural municipalities going beyond the binding policies required in the source protection plans. However, there was still opposition of some policies from rural municipalities in both regions, usually due to fears regarding the financial cost of implementation. Conservation authority staff participants explained that any conflict or opposition of binding policies would be met with further education and outreach. Even though decisions may not have always been well received, there were venues within the process for multiple stakeholders to discuss and debate issues. This process increased communication and linkages between implementing bodies, as well as commitment to policy decisions.

Social norms and valuing of water have shifted since the Walkerton tragedy, as well as the awareness of water issues. The educational opportunities provided during the process resulted in an increase of local knowledge compared to before the CWA. For example, one conservation authority staff 
explained, "It was one of the best things that source protection did was to give people maps that show them where their water comes from" (CA Participant). However, as there had not been any recent drinking water incidents in both regions, it was thought that most people with municipally supplied drinking water take it for granted. As far as the effectiveness of public education and outreach efforts a conservation authority staff member explained, "...more broadly we didn't do a lot of that necessarily in terms of advancing knowledge on a broader community" (CA Participant). Evidently, there is still work to be done. Again, as with other capacity building efforts, the plan for the future is unknown, but ongoing outreach and education is being discussed between conservation authorities and municipalities. There is some required outreach and education on certain items in the source protection plans themselves, which incorporates fact sheets, websites and children's water festivals. However, five participants noted the unknown ongoing provincial funding for SWP implementation could constrain future outreach and education efforts. Two participants indicated that the risk management officials have played an important function in building social capacity. Part of the risk management official's role has been explaining the reasons for certain policies to those impacted by implementation. These types of methods have increased knowledge at the local level, as well as have contributed to slowly shifting social norms.

\subsection{Technical/Human}

Technical/human capacity refers to the physical and operational ability of an organization to perform SWP management and operations adequately. This also incorporates having human resources, with adequate knowledge, skills and experience to properly create source protection plans and implement needed measures [12,20]. In total, 27/30 informants spoke about technical/human capacity in their interview. Again, similar to the other facets of capacity for SWP the CWA built technical/human capacity in the case study regions (Table 2). Seventeen participants noted the development of technical capacity at the municipal level. This increase in technical capacity was attributed to technical aid from the conservation authorities and Ministry of the Environment and Climate Change liaisons (who sat on source protection committees) (Table 7). Funding from the Ministry of the Environment and Climate Change raised technical/human capacity at the conservation authority level. The conservation authorities were integral in providing staff with technical expertise that facilitated the process and who physically wrote the source protection plans. Particularly for rural municipalities, conservation authorities provided much needed support in all facets of the process, including implementation. One municipal staff member explained,

"The North Bay-Mattawa Conservation Authority kind of spearheaded the whole thing. Basically, I believe we got funding, and then we just basically gave them the funding. And then they hired a consultant to take care of the official plan and zoning bylaw amendments" (Municipal Participant).

A conservation authority staff member explained, "I think the local decision makers have enough support that even if they don't have a deep understanding themselves they've got the resources at their finger tips and we are always a phone call away too" (CA Participant). Eighteen participants noted that the process under the CWA has increased human capacity both at the conservation authority level, and in some cases at the municipal level with funding for risk management officials (Table 7). Some smaller municipalities have deferred their risk management responsibilities to the conservation authority. What is of concern is the ongoing support for staff members at the conservation authority. One criticism of the CWA, expressed by one source protection committee member, was that it was legislation to make a product (the source protection plan) and there has not been enough attention to sustaining, particularly, the conservation authorities' role. One source protection committee member explained,

"Conservation authorities are getting tired. They have no more fiscal and internal capacity to devote to this. They've got to be satisfied that there is a sustainable flow of resources to allow them to continue to do this in a partnership. They can't keep doing this just because it is good for you. Conservation authorities' resources are limited and stretched, and they often beg for help from other 
authorities. And that is why the argument is that senior levels of government have got to get behind this" (SPC Participant).

Though this statement relates to financial capacity constraints as well, the decrease in provincial funding has resulted in decreased technical staff at the conservation authorities. As mentioned previously some conservation authorities noted keeping staff on to work on other projects, however this could not be done for all staff. Even if more funding was available in further planning and implementation efforts, important institutional knowledge has now been lost, as those original staff members have gone on to different organizations. One source protection committee member noted it will be more difficult for conservation authorities such as the North Bay-Mattawa Conservation Authority, who are smaller and do not have staff at near by conservation authorities to collaborate with.

Table 7. Key Findings for Technical/Human Capacity.

\begin{tabular}{lc}
\hline \multicolumn{1}{c}{ Indicators of Presence } & No. of Interviews Confirming Indicator \\
\hline $\begin{array}{l}\text { Data Created and Shared During the Creation of the Assessment Reports, } \\
\text { Increased Technical Capacity, Especially for Rural Municipalities. }\end{array}$ & 24 \\
\hline $\begin{array}{l}\text { Human Capacity for SWP Efforts Increased at the Conservation Authorities and } \\
\text { Some Municipalities. }\end{array}$ & 18 \\
\hline $\begin{array}{l}\text { The Provincial Government and Conservation Authorities Provided Technical } \\
\text { Support to Municipalities, Aiding in Creating Understanding about Reasons for }\end{array}$ & 17 \\
SWP and their Role in Implementation. & 14 \\
\hline $\begin{array}{l}\text { Technical Capacity was Raised for those on the Source Protection Committees via } \\
\text { Educational Resources, Presentations and Co-Learning. }\end{array}$ & 10 \\
\hline $\begin{array}{l}\text { Some Municipal Staff and Elected Officials Do not Have the Expertise to } \\
\text { Understand the Need for SWP, Making Re-Education Programs Imperative. }\end{array}$ & 10 \\
\hline $\begin{array}{l}\text { There Were Some Issues with the Technical Guidelines (e.g., Tables of Drinking } \\
\text { Water Threats, Vulnerability Ratings, and Capture Zone Delineations). }\end{array}$ & \\
\hline $\begin{array}{l}\text { As Provincial Funding Declines so Does the Maintenance of Technical/Human } \\
\text { Capacity. The Lack of Guaranteed Future Funding for Continual Evaluation and } \\
\text { Monitoring of Local Circumstance is a Concern. Particularly, in Order to Keep } \\
\text { Data and Policies up to Date in Regard to Current and Future Threats. }\end{array}$ & 7 \\
\hline
\end{tabular}

Learning opportunities and the building of technical capacity during the planning process was high. As previously explained there was a significant amount of technical training devoted to the source protection committee members. Fourteen participants noted technical capacity being raised for those on the source protection committees via educational resources, presentations and co-learning (Table 7). Furthermore, working groups were created during the planning process. These working groups included source protection committee members as well as additional municipal representatives and others who would be eventually impacted by policy decisions. Presentations on certain topics of interest were also given at the source protection committee meetings as well as the working group meetings. Varied skillsets and expertise (academics, environmental lawyers, activists, etc.) allowed source protection committee members to learn from each other. However, it was noted that committee members could be overwhelmed by the amount of technical information that they were required to absorb. A conservation authority staff member explained, "even technical staff were challenged with the amount of information we had to go through" (CA Participant). Agricultural representatives were provided with additional training and support by the Ontario Farm Environmental Coalition, Ontario Federation of Agriculture, and Ontario Ministry of Agriculture, Food and Rural Affairs. Three participants noted this additional aid to agricultural representatives as beneficial. For example, in the NBMSPA there was a technical dispute related to a potential agricultural threat where the Ontario Farm Environmental Coalition provided data and expertise in support of their agricultural representative. Furthermore, the function of the Ministry of the Environment and Climate Change liaison was noted by two participants as important in providing technical capacity to source protection committees, as well as creating a link to other provincial ministries such as the Ministry of Natural Resources and Forestry, Ontario Ministry of Agriculture, Food and Rural Affairs, and the Ministry of Transportation. 
The process under the CWA was effective for educating municipalities, and getting them prepared for their role in implementation. However, more ongoing education needs to be in place. Ten informants noted municipal staff and elected official's understandings of the need for SWP could be a potential barrier to implementation (Table 7). This is especially the case if re-education of municipal staff and elected officials does not occur in the future. Three participants indicated, due to the nature of the four-year cycle of elected government, it has to be an ongoing effort to ensure municipal actors understand the reasons for these policies. A source protection committee member explained,

"You cannot make assumptions about the capacity and expertise and knowledge of individual municipalities as a static, as a given. Municipalities come in all different sizes, over time people retire, people move on, elected officials move on. New people come in and we don't know what their backgrounds are. So, there will be this constant rebuilding of knowledge and history as people move out and new people take their place. Elected, administrative, and even in the communities themselves" (SPC Participant).

Municipalities, especially smaller ones, lacking internal expertise, may not always understand the science behind the source protection plan and related policies. However, 20 participants agreed municipalities do understand their role in implementation (see Section 3.1). The ongoing re-education of newly elected officials and municipal staff is critical. Notably, the risk management officials, who enforce policies under the source protection plans, have gone through significant training. Risk management officials (often municipal employees but sometimes this role has been deferred to the conservation authority) continue to work with consultants and provincial staff in interpreting guidelines. The risk management official also serves as an interpreter to municipal staff and elected officials in SWP under the CWA.

In regard to access to adequate data for SWP, data gathered for the assessment reports have derived important baseline information for the regions involved, and this has been an important benefit of the planning process. It was noted by 24 participants that the data created and shared during the creation of the assessment reports, increased technical capacity, especially for rural municipalities (Table 7). There are now studies to inform decisions. Though, as mentioned, data sharing was effective between provincial ministries, two participants noted that structures are needed for more formal and strategic data sharing in regard to source water supplies. Increased staff at the conservation authority level would also be needed to implement a collaborative data-sharing program. Technical guidelines that contributed to the making of policies in the source protection plans, such as the Tables of Drinking Water Threats and guidelines for how to assess vulnerability and classify intakes and wells, were valuable for creating consistent, transparent and technically defensible policies. However, 10 participants noted issues with the technical guidelines (e.g., Tables of Drinking Water Threats, vulnerability ratings, and capture zone delineations) (Table 7). The prescriptive nature of the technical guidelines sometimes made it hard to apply to local circumstance. Both case study regions wanted to expand beyond the prescribed list of threats in areas such as threats for Lake Ontario intakes, threats related to clusters of private drinking water wells, and threats related to pipelines. There were also noted limitations by seven participants regarding the rigidness of capture zone delineations based on groundwater model simulations. A consultant involved in the process explained,

"the concern lies in how much faith we put into the results of the model. Models can create lines on a map that non-modellers will adopt as fact and may then create real world rules (i.e., planning decisions) based on the position of a line (a time of travel capture zone) that itself is only a generalization, and quite possibly an educated guess at best" (Other Participant).

One risk management official explained that some consultants conducting modelling for the assessment reports were not aware of how models would be used in the whole process. It is clear throughout the planning process, the focus was on intake protection zones, versus watershed protection. One source protection committee member explains, 
"The only thing, [a] limitation would be the fact that the reports, after you did the characterization report, everything started to focus only on drinking water intake zones, which really rammed us back to prior to the Clean Water Act. I mean we have always been looking at intake zones, so, we haven't really moved into a watershed [plan]" (SPC Participant).

In the end, though this first round of planning was essential for building technical capacity for SWP, it did not always allow for all locally specific issues to be addressed. Therefore, there is need for further evaluations of threats. For example, one area of concern expressed by 10 participants in regard to future threats to be evaluated was the impact of climate change on source water supplies. Conservation authorities are tasked in annual reviews and creating new work plans, and can apply to the Minister for further inquiry into specific topics of interest. There is a need to keep the science and policies in the source protection plans up to date. Seven participants indicated that as provincial funding declines to the source protection program so does the maintenance of the built technical/human capacity (Table 7). SWP cannot succeed if plans are stagnant. Technical and human capacity to undertake technical studies must be maintained to adequately protect source water supplies now and into the future.

\section{Discussion}

SWP capacity under the CWA has been very strong throughout the process. The legislated process has effectively built capacity in municipalities, especially in those rural municipalities that lack capacity internally and benefit from such regional and/or collaborative programs. The process brought stakeholders and actors together at a watershed level to discuss drinking water protection, something in some cases that had not been done before. There is much that rural Canada can learn from this process. First, it is clear that enforceable legislation is critical for ensuring SWP policies are implemented. However, the legislation must strike a balance of providing adequate power for enforcement and consistency while allowing for locally relevant policy options. In addition, having the program and technical guidelines clearly scoped before the process begins reduces inefficiencies and frustrations with the process. The 2016 Ontario Auditor General's report criticizes the process for taking nearly 17 years after the Walkerton tragedy to create source protection plans. Reasons noted by the Auditor General for this lengthy process include the Ministry's lack of a clear time frame for plan approval and that some plans submitted were deemed incomplete [34]. In the wake of the Walkerton tragedy, the program was understandably rolled out in haste, making the entire process essentially a provincial wide pilot project that is continuing to evolve. The 2014 and 2016 Ontario Auditor General reports note several weaknesses in the source protection plans themselves: the plans did not address all potential threats (e.g., spills from industrial and commercial facilities to drinking water intakes in the Great Lakes); plans do not protect those on private wells or single resident intakes (over 1.6 million Ontarians); and plans did not address risks of abandoned wells to groundwater. There were also issues flagged regarding non-compliance with the Nutrient Management Act, and the Ministry's weak enforcement of this Act. It is noted in the 2016 Auditor General report that the Ministry of the Environment and Climate Change is making progress on these issues [34]. However, the source protection plans were created assuming other SWP related legislation, such as the Nutrient Management Act, were being properly implemented and enforced. As described, source protection committees focussed on creating policies where there were current gaps in legislation and regulatory controls. The incidences of non-compliance with the Nutrient Management Act may mean there are gaps in the source protection plans for addressing threats related to nutrients. Ensuring that the institutional effectiveness of the CWA and the source protection plans are maintained will require constant monitoring and evaluations of the plans. In addition, though some First Nation communities were elevated into their region's source protection plan in other parts of the province, there are still barriers to First Nations involvement. These barriers need to be addressed in a meaningful way. Hanrahan (2017) explained that addressing water security for Indigenous peoples requires, “ $\ldots$ an open discussion of Canadian national identity with all its dimensions considered, including colonialism, and a maturation of Canadian liberal democracy to include Indigeneity and Indigenous 
rights" [35] (p. 84). The involvement of First Nation communities in SWP under the CWA requires better efforts and a different approach than has been employed in this first phase of planning. There was indication from provincial participants that this issue is being given serious consideration in the next phase of planning.

Thus far, financial capacity has been sufficient; however, the unknown mechanisms for sustainable funding have affected SWP decisions. The intention of the program was for shared SWP responsibilities, including financial obligations of implementation. Financial ownership by municipalities, especially rural municipalities, is lacking. Conservation authorities, acting as the source protection authorities, worked well in the Ontario context. They were noted repeatedly as the source of technical and social capacity for rural municipalities. Conservation authorities rely on municipal funding for survival. Conservation authorities will require further funding from provincial and municipal sources to maintain their current role in SWP under the CWA, so they do not continue to lose capacity to serve local municipalities. Currently, the Ministry of the Environment and Climate Change lacks a long term fiscal strategy to ensure municipalities and conservation authorities are funded in source protection plan implementation and maintenance [34]. Unfortunately, the nature of government means that funding is at the whim of the political will of the day. More strategic financial plans and fiscal frameworks are needed to ensure funding is continued for SWP. Municipalities also have the responsibility of ensuring that this occurs. However, maintaining sustainable funding sources is particularly difficult for rural municipalities. Especially for rural municipalities, future fiscal frameworks need to be thoughtfully considered. Financial concerns continue to be one of the greatest roadblocks in implementation of SWP, as seen in the community of Trout Creek who opted out of the process under the CWA after realizing the financial consequences of potential policies. Furthermore, current source protection plans and policies will lose effectiveness if not continually updated and supported by enforcements tools (e.g., legislation, regulations, local zoning and by-laws, and the human resources to enact enforcement). Guaranteed financial capacity for continued support of risk management officials and continued implementation (e.g., septic system inspections currently being conducted by conservation authority staff) has been questioned. The 2014 and 2016 Ontario Auditor General report states that Ontario has low cost recovery rates for industrial and commercial facilities that take water. This was due to low fees paid by limited companies ( $\$ 3.71$ for every million litres they drew) [34]. The valuing of water needs to increase if we want to create operational fiscal frameworks to adequately pay for SWP as well as other drinking water related expenses. Since the release of the 2016 Ontario Auditor General report, there has been some progress in the valuing of water. As of 1 August 2017 Ontario will raise fees to $\$ 503.71$ for every million litres of groundwater taken. Furthermore, the Minister of Environment and Climate Change announced a moratorium on new or expanding water takings by bottling companies until 1 January 2019 [36]. Ultimately, institutional measures such as legislation and governance structures need to be matched with fiscal frameworks to support these structures. Finding efficiencies in regional collaborations could offer promise for rural municipalities [11].

SWP poses complex problems in implementation and requires the integration of expert science, local knowledge, community beliefs and values [10,37]. Legislation alone is useless unless those required to enact it commit to doing so. Fostering this type of commitment requires the building of social capacity. It is clear that social capacity was built during the creation of the source protection plans. The process under the CWA brought together diverse stakeholders through various methods including the source protection committees and public engagement events to create the source protection plans. However, it was noted that engagement techniques could be more creative in order to eliminate barriers to engagement, such as long travel distances to events [38]. This is particularly a concern in rural areas with large spread out geographies. The creation of lay summaries of the plan and accessible information is important. Participants involved in the SWP planning process hoped that this type of public outreach will continue, but some doubted whether the current level of enthusiasm can be sustained. It was the general sentiment of informants that if people turn on their water and it is safe and 
clean, then they stop caring about the need for SWP actions. However, "SWP has no clear end-point, it requires ongoing societal involvement" [10] (p. 228). Just because there is no perceived or current issue with drinking water, that does not mean there cannot be an issue in the future. The nature of water and the environment in general is that it is constantly changing and evolving, and so are threats to drinking water. Threat identification and mechanisms for mitigation should be a collaborative effort $[23,24]$. Especially in rural areas, landowners and the general public are required to implement SWP through actions in ways such as reducing fertilizer use and ensuring septic systems within contributing areas are properly maintained. People need to be continually reminded of the importance of SWP, and their role in it. How public engagement in the process occurs should be re-evaluated so that citizens continue to be active participants in SWP. It is important that engagement is not just simply done, but is effective. Further ongoing work is needed to continue to increase and maintain social capacity for SWP in the case study regions. Help from non-governmental organizations in engagement efforts could aid in diversifying engagement techniques and participating audiences.

Technical and human capacity was raised significantly during this process through extensive education and training, data sharing and increases in human resources devoted to SWP. The education and time invested in decision makers (those on source protection committees) as well as implementers (such as the risk management officials) has been immense. Notably, the support and training of agricultural representatives by the Ontario Farm Environmental Coalition SWP working group, has built capacity with these important stakeholders [39]. Other studies have shown that information sharing was valuable during the visioning and early stages of policy development and it increased efficiencies and consistency throughout the province. Having structures in place where these types of information sharing and co-learning can occur will be increasingly important as monitoring, evaluations, and amending of source protection plans occur [40]. It was noted that conservation authorities, like the North Bay-Mattawa Conservation Authority, who do not neighbour another conservation authority, might be at a disadvantage, as they lack the opportunity to collaborate on certain technical endeavours. Ways to connect conservation authorities with other SWP partners will continue to be important, and may require more formal collaboration (e.g., structured data sharing programs) to continue. Furthermore, ongoing education of all involved in implementation must continue to occur, specifically for elected officials at the local level who go through constant four-year turnovers. Additionally, more evaluation of local circumstance and support for keeping data and policies up to date is required. Murray and Roth (2012) also found that SWP requires adaptive approaches that embed evaluation to adequately address current and potential threats [41]. Adaptive approaches are difficult if funding for monitoring, evaluation, future planning and continued implementation is unknown. Recent studies have shown that engaging the public in community-based water monitoring can be a viable option when government funding declines. However, these types of programs still need to be provided with adequate financial, institutional, social and technical/human capacity to succeed [42]. Human capacity has already been diminished from its original level in the preliminary phases of the creation of the source protection plans. Maintaining current levels of technical/human capacity will be difficult, especially if provincial funding for the program continues to decline.

\section{Conclusions}

Ultimately, the SWP process under the CWA has been successful for building capacity for SWP in the rural municipalities that were included under the protection of the Act (i.e., those with municipally operated drinking water systems). This research found that SWP in rural areas needs: enforceable mandatory legislation; sustainable provincial funding and municipal fiscal frameworks to support ongoing SWP planning and implementation; technical aid at the regional level; and support and commitment to SWP at the local level (e.g., municipalities, local health units, landowners, residents and watershed users). It was suggested by participants that if other places in rural Canada were to adopt a similar type process, they would have to critically select the aspects of the program that would 
be appropriate for their local context. This coincides with other research suggesting that proper SWP policy transfer needs to have "consideration of the political and institutional, resources and capacity, cultural, and biophysical contexts of the original and receiving jurisdictions"[43] (p. 95).

A question arising from this research is whether the SWP capacity built in Ontario is sustainable? There are considerable concerns about where this program will go from here, and what will be the result if municipalities (especially already fiscally limited rural municipalities) are required to pay for all ongoing implementation. Through this process, it was indicated that municipalities deliberatively made policies with financial restrictions in mind, such as imposing outreach and education policies rather than policies that may require a risk management official to oversee. However, is that right? Is that part of the needed compromise of SWP, or have these financial restrictions diluted the potency of the plans and their policies in protecting drinking water sources? The next iterations of these plans and further clarifications of the CWA will have significant implications for rural Ontario. Will it include those other areas part of the rural landscape such as First Nations reserves, those on private wells or those municipalities located outside of a conservation authority boundary? As exemplified by the attempt to elevate the community of Trout Creek's private well cluster into the NBMSPA's plan, the current process cannot be directly transferred to unserviced rural areas. Further research is required on the best ways to include private and First Nation drinking water systems into the CWA, to ensure those residents reliant on these systems have adequate drinking water protection. Collaborative frameworks, such as the one under the CWA, offer promise, and have indeed raised SWP capacity for the rural municipalities involved. However, Ontario cannot become complacent with its admirable SWP efforts. Source protection plans are not meant to sit on a shelf. They should be living documents that are constantly implemented through local and provincial planning decisions, landowner actions, and citizen behaviours. Funding to keep these plans alive and vital (e.g., containing up-to-date science, implemented by necessary actors, inclusive of all drinking water systems) is evidently still an unresolved topic for future debate.

Acknowledgments: This research would not be possible without the generous support of the MITACS-internship program, The Harris Centre- RBC Water Research and Outreach Fund, and the Rural Policy Learning Commons. Thank you to my supervisors Kelly Vodden, Maura Hanrahan and Robert Scott for their continual guidance and support of this research. In addition, thank you to all the participants in this research project for their generous donation of their time and expertise.

Conflicts of Interest: The author declares no conflict of interest. The funding sponsors had no role in the design of the study; in the collection, analyses, or interpretation of data; in the writing of the manuscript, and in the decision to publish the results.

\section{Appendix}

Table A1. Elements of Capacity for Source Water Protection *.

\begin{tabular}{|c|c|}
\hline Element & Definitions and Indicators \\
\hline Institutional & $\begin{array}{l}\text { The legislation, regulations, policies, protocols, governance arrangements and delegation of } \\
\text { responsibility to plan and enact SWP. Example indicators include: } \\
\text { - } \quad \text { Provincial legislation and policies provide guidance for drinking water protection at the } \\
\text { local level } \\
\text { - } \quad \text { Municipal planning strategies and by-laws protect current drinking water supplies } \\
\text { - } \quad \text { sand use activities are controlled in municipal well field, recharge and watershed water } \\
\text { - } \quad \text { Land has been purchased for the protection of current municipal water supplies } \\
\text { - } \quad \text { Plans have been developed to guide municipal actions during water quality emergencies } \\
\text { - } \quad \text { All responsible for SWP know their responsibilities for implementation and enforcement } \\
\text { - Institutional arrangements for land water management is integrated } \\
\text { - Local land use planning supports SWP at a watershed or regional level }\end{array}$ \\
\hline
\end{tabular}


Table A1. Cont.

\begin{tabular}{|c|c|}
\hline Element & Definitions and Indicators \\
\hline Financial & $\begin{array}{l}\text { The ability to acquire adequate funds to pay for SWP efforts as well as for ongoing planning, } \\
\text { governance and management efforts. Example indicators include: } \\
\text { - } \quad \text { Organizations responsible for protecting source water supplies are able to maintain a } \\
\text { balanced budget } \\
\text { - Organizations responsible for protecting source water supplies are able to obtain funding } \\
\text { from outside sources } \\
\text { - Water rates for customers reflect the full cost of protecting and providing municipal } \\
\text { drinking water (including treatment, distribution, maintenance, and SWP) } \\
\text { - Funding is available for municipal SWP projects } \\
\text { - Financial mechanisms are used to reduce water use (e.g., water rates charged by municipal } \\
\text { water utility are used to reduce water consumption) }\end{array}$ \\
\hline Social & $\begin{array}{l}\text { The social factors that influence SWP governance and implementation. This includes social norms } \\
\text { (e.g., values, attitudes, behaviours, sense of place, trust, reciprocity, commitment and motivation) } \\
\text { that impact public awareness, stakeholder involvement, community support, and public and } \\
\text { private partnerships in SWP efforts. This also incorporates structural networks, communications } \\
\text { and the relationships between different groups interests and actors. Example indicators include: } \\
\text { - } \quad \text { Clear leadership for water quality protection at the watershed level exists } \\
\text { - Active linkages between municipality and provincial agencies exist (vertical linkages) } \\
\text { - Active linkages among watershed municipalities exist (horizontal linkages) } \\
\text { - } \quad \text { Active linkages between municipality and community organizations exist } \\
\text { (horizontal linkages) } \\
\text { - Community awareness and support for watershed protection }\end{array}$ \\
\hline Technical/Human & $\begin{array}{l}\text { The physical and operational ability of an organization to perform SWP management and } \\
\text { operations adequately. In addition, having the human resources, with adequate knowledge, skills } \\
\text { and experience to properly create source protection plans and implement needed measures. } \\
\text { Example indicators include organizations responsible for protecting source water supplies have: } \\
\text { - Employees dedicated to water management } \\
\text { - } \quad \text { Access to individuals with the necessary skills and training to manage drinking water } \\
\text { - Education and training opportunities available to staff members and decision makers } \\
\text { - Access to individuals with the expertise needed to undertake technical activities related to } \\
\text { drinking water quality } \\
\text { - Access to the data needed to manage water supplies, delineate watersheds and aquifers, and } \\
\text { develop source protection plans }\end{array}$ \\
\hline
\end{tabular}

Note: * Indicators based on: [5,12,20,44,45].

\section{References}

1. Livernois, J. The Economic Costs of the Walkerton Water Crisis; Ontario Ministry of the Attorney General: Toronto, ON, Canada, 2002; p. 53.

2. De Loë, R.C.; Murray, D.; Michaels, S.; Plummer, R. Policy Transfer Among Regional-Level Organizations: Insights from Source Water Protection in Ontario. Environ. Manag. 2016, 58, 31-47. [CrossRef] [PubMed]

3. O'Connor, D.R. Part One: A Summary: Report of the Walkerton Inquiry: The Events of May 2000 and Related Issues; Ontario Ministry of the Attorney General: Toronto, ON, Canada, 2002; pp. 1-35.

4. O'Connor, D.R. Part Two: Report of the Walkerton Inquiry: A Strategy for Safe Drinking Water; Ontario Ministry of the Attorney General: Toronto, ON, Canada, 2002; p. 540.

5. Ivey, J.L.; De Loë, R.C.; Kreutzwiser, R.D.; Ferreyra, C. An Institutional Perspective on Local Capacity for Source Water Protection. Geoforum 2006, 37, 944-957. [CrossRef]

6. Hrudey, S.E.; Payment, P.; Huck, P.M.; Gillham, R.W.; Hrudey, E.J. A Fatal Waterborne Disease Epidemic in Walkerton, Ontario: Comparison with Other Waterborne Outbreaks in the Developed World. Water Sci. Technol. 2003, 47, 7-14. [PubMed]

7. Patrick, R.J. Uneven Access to Safe Drinking Water for First Nations in Canada: Connecting Health and Place through Source Water Protection. Health Place 2011, 17, 386-389. [CrossRef] [PubMed] 
8. Baird, J.; Plummer, R.; Morris, S.; Mitchell, S.; Rathwell, K. Enhancing Source Water Protection and Watershed Management: Lessons from the Case of the New Brunswick Water Classification Initiative. Can. Water Res. J./Rev. Can. Res. Hydr. 2014, 39, 49-62. [CrossRef]

9. De Loë, R.C.; Kreutzwiser, R.D. Closing the Groundwater Protection Implementation Gap. Geoforum 2005, 36, 241-256. [CrossRef]

10. Simpson, H.C.; De Loë, R.C. A Collaborative Approach to Groundwater Protection: The Rural Water Quality Program for Waterloo Region. Can. Water Can. Water Res. J./Rev. Can. Res. Hydr. 2014, 39, 37-41. [CrossRef]

11. Minnes, S.; Vodden, K. The Capacity Gap: Understanding Impediments to Sustainable Drinking Water Systems in Rural Newfoundland and Labrador. Can. Water Res. J./Rev. Can. Res. Hydr. 2017, 42, 163-178. [CrossRef]

12. Rawlyk, F.X.; Patrick, R.J. Capacity Needs for Source Water Protection Plan Implementation: Lessons from the South Saskatchewan River. Can. J. Urban Res. 2013, 22, 20-45.

13. Hrudey, S.E. Safe Drinking Water Policy for Canada; C.D. Howe Institute: Toronto, ON, Canada, 2011; p. 36.

14. De Loë, R.C.; Kreutzwiser, R.D.; Neufeld, D. Local Groundwater Source Protection in Ontario and the Provincial Water Protection Fund. Can. Water Can. Water Res. J./Rev. Can. Res. Hydr. 2005, 30, 129-144. [CrossRef]

15. Plummer, R.; Velaniskis, J.; de Grosbois, D.; Kreutzwiser, R.D. The Development of New Environmental Policies and Processes in Response to a Crisis: The Case of the Multiple Barrier Approach for Safe Drinking Water. Environ. Sci. Policy 2010, 13, 535-548. [CrossRef]

16. Mitchell, B.; Priddle, C.; Shrubsole, D.; Veale, B.; Walters, D. Integrated Water Resource Management: Lessons from Conservation Authorities in Ontario, Canada. Int. J. Water Res. Dev. 2014, 30, 460-474. [CrossRef]

17. Ontario Government. Clean Water Act. 2002 (S.O. 2006, Chapter 22). ON, Canada, 2006. Available online: https:/ /www.ontario.ca/laws/statute/06c22 (accessed on 11 April 2017).

18. Ontario Ministry of the Environment and Climate Change. The Clean Water Act: Promoting Municipal Awareness and Understanding; Government of Ontario: Toronto, ON, Canada, 2006.

19. Ontario Ministry of the Environment and Climate Change. Source Protection. Available online: https: / / www.ontario.ca/page/source-protection (accessed on 15 March 2017).

20. Robins, L. Making Capacity Building Meaningful: A Framework for Strategic Action. Environ. Manag. 2008, 42, 833-846. [CrossRef] [PubMed]

21. Robins, L. Nation-Wide Decentralized Governance Arrangements and Capacities for Integrated Watershed Management: Issues and Insights from Canada. Environments 2007, 35, 1-47.

22. Norman, E.; Bakker, K. Transgressing Scales: Water Governance across the Canada-U.S. Borderland. Ann. Assoc. Am. Geogr. 2009, 99, 99-117. [CrossRef]

23. Ananda, J.; Proctor, W. Collaborative Approaches to Water Management and Planning: An Institutional Perspective. Ecol. Econ. 2013, 86, 97-106. [CrossRef]

24. Emerson, K.; Nabatchi, T.; Balogh, S. An Integrative Framework for Collaborative Governance. J. Public Adm. Res. Theory 2012, 22, 1-29. [CrossRef]

25. Ivey, J.L.; De Loë, R.C.; Kreutzwiser, R.D. Planning for Source Water Protection in Ontario. Appl. Geogr. 2006, 26, 192-209. [CrossRef]

26. Kot, M.; Castleden, H.; Gagnon, G.A. Unintended Consequences of Regulating Drinking Water in Rural Canadian Communities: Examples from Atlantic Canada. Health Place 2011, 17, 1030-1037. [CrossRef] [PubMed]

27. Yin, R. Qualitative Research from Start to Finish; The Guilford Press: New York, NY, USA, 2011.

28. Ontario Ministry of Agriculture, Food and Rural Affairs. Rural Economic Development Program. Available online: http:/ / www.omafra.gov.on.ca/english/rural/red/guidelines.htm (accessed on 17 March 2017).

29. Statistics Canada. Census Profile. Available online: http://www12.statcan.gc.ca/census-recensement/2011/ dp-pd/prof/index.cfm?Lang=E (accessed on 30 March 2017).

30. Cataraqui Source Protection Committee. Cataraqui Source Protection Plan; Cataraqui Source Protection Committee: Glenburnie, ON, Canada, 2014; p. 219.

31. North Bay-Mattawa Source Protection Committee. North Bay-Mattawa Source Protection Area: Source Protection Plan; North Bay-Mattawa Source Protection Committee: North Bay, ON, Canada, 2015; p. 103. 
32. Ontario Ministry of the Environment and Climate Change. Source Protection Areas \& Regions. Available online: http://www.conservation-ontario.on.ca/images/SWP/SPPBoundaryMap_South_.pdf (accessed on 11 April 2017).

33. Ontario Government. Safe Drinking Water Act. 2002 (S.O. 2002, Chapter 32). Ontario, Canada, 2002. Available online: https:/ / www.ontario.ca/laws/statute/02s32 (accessed on 11 April 2017).

34. Ontario Auditor General. Source Water Protection. In 2016 Annual Report; Queen's Printer for Ontario: Toronto, ON, Canada, 2016; Volume 2, pp. 156-167.

35. Hanrahan, M. Water (In)Security in Canada: National Identity and the Exclusion of Indigenous Peoples. $\mathrm{Br}$. J. Can. Stud. 2017, 30, 69-89. [CrossRef]

36. CBC. Ontario Confirms Bottled Water Companies to Pay More as of August 1. Available online: http:/ / www. cbc.ca/news/canada/kitchener-waterloo/ontario-bottled-water-taking-fee-going-up-1.4151685 (accessed on 13 June 2017).

37. Simpson, H.; De Loë, R.C.; Andrey, J. Vernacular Knowledge and Water Management- towards the Integration of Expert Science and Local Knowledge in Ontario, Canada. Water Altern. 2015, 8, 352-372.

38. Huck, D. A Question of Perspective: Opportunities for Effective Public Engagement in Watershed Management Planning in Manitoba; University of Manitoba Winnipeg: Manitoba, MB, Canada, 2012; p. 235.

39. Simpson, H. The Agricultural Community and its Contribution to Collaborative Environmental Problem-Solving; University of Waterloo: Waterloo, ON, Canada, 2014; p. 296.

40. Murray, D.; De Loë, R.C. Information Sharing for Source Water Protection in Ontario; Water Policy and Governance Group: Waterloo, ON, Canada, 2013; p. 19.

41. Murray, D.; Roth, A.P. Review of Options for Evaluating Policies Created for Source Protection Planning in Ontario; Water Policy and Governance Group, University of Waterloo: Waterloo, ON, Canada, 2012; p. 21.

42. Garda, C.; Castleden, H.; Conrad, C. Monitoring, Restoration, and Source Water Protection: Canadian Community-Based Environmental Organizations' Efforts towards Improving Aquatic Ecosystem Health. Water 2017, 9, 212. [CrossRef]

43. De Loë, R.C.; Murray, D. Contextual Considerations Shaping the Transferability of Policies for Drinking Water Source Protection. In Water Governance, Policy and Knowledge Transfer; De Boer, C., Vinke-de Kruijf, J., Ozerol, G., Bressers, H., Eds.; Routledge: Abingdon, UK, 2013; pp. 92-110.

44. Noble, B.; Basnet, P. Capacity for Watershed Cumulative Effects Assessment and Management in the South Saskatchewan Watershed, Canada. Can. Water Can. Water Res. J./Rev. Can. Res. Hydr. 2015, 40, 187-203. [CrossRef]

45. Timmer, D.K.; De Loë, R.C.; Kreutzwiser, R.D. Source Water Protection in the Annapolis Valley, Nova Scotia: Lessons for Building Local Capacity. Land Use Policy 2007, 24, 187-198. [CrossRef] 